\title{
Efficient forest fuel supply systems: Research, development and dissemination of knowledge in Sweden
}

\author{
by Maria Iwarsson Wide 1
}

\begin{abstract}
Efficient Forest Fuel Supply Systems (ESS) was run as a collaboration program, financed by the forestry sector, the energy sector, and the Swedish Energy Agency. The objective was to enable a long-term, sustainable and greatly increased use of forest fuel by supporting the development of a more efficient production system. The financial framework of ESS was SEK 130 million (approximately CA \$ 19.5 million) over eight years, and the program supported approximately 150 research and development projects. Skogforsk administered the program, and was responsible for coordination and disseminating information to the stakeholders. A program board made formal decisions, and a fuel technology collaboration group helped to identify R\&D areas. A project pilot was linked to each project to ensure that the focus was on sector needs and interests, and to help the project manager with relevant study objects, networks and updated information. In and around the program, valuable expertise and networks were built up in each sector and in research organisations, both nationally and internationally. Great emphasis was placed on practical demonstration, implementation and communication, in order to disseminate knowledge about new technology and methods and to influence attitudes toward forest fuel harvest. The forestry sector and its contractors gradually strengthened the supply system through improved skills, better organisation, and advanced equipment. The goals were largely attained, and practical aspects relating to forest fuel were implemented, incorporating many of the results.
\end{abstract}

Keywords: primary forest fuel harvest and handling, cooperation program, bioenergy, knowledge implementation.

\section{RÉSUMÉ}

Le programme Efficient Forest Fuel Supply Systems-ESS (Systèmes efficaces d'approvisionnement en combustible forestier) était un programme coopératif financé par le secteur forestier, le secteur de lénergie et l'Agence énergétique de Suède. Il avait pour objectif de permettre une utilisation à long terme, durable et accrue de combustibles forestiers en favorisant la mise sur pied d'un système de production plus efficace. Le cadre financier d'ESS prévoyait des investissements totalisant 130 millions de couronnes suédoises (environ 19,5 millions de dollars canadiens) sur une période de 8 ans; il aura permis de soutenir près de 150 projets de recherche et de développement. Skogforsk a assuré la gestion du programme et avait la responsabilité de coordonner et de diffuser les renseignements aux différents partenaires. Les décisions stratégiques relevaient du bureau de direction alors qu'un groupe d'experts en technologie des combustibles soccupait d'identifier les domaines de recherche et de développement. Il y avait un projet pilote rattaché à chaque système afin de mettre laccent sur les intérêts et les besoins du secteur et pour fournir au gestionnaire du projet les objets de létude, les contacts utiles et les informations les plus à jour. L’ensemble du programme aura permis de développer une expertise et un réseau de contacts utiles dans chaque secteur et chez les organismes de recherche, tant à léchelle nationale que sur la scène mondiale. Laccent a été mis principalement sur des démonstrations pratiques, le transfert technologique et les communications, de façon à faire circuler les connaissances rattachées aux nouvelles technologies et méthodes et pour modifier les attitudes sur la récolte de combustibles forestiers. Les entrepreneurs du secteur forestier ont graduellement fait évoluer le système d’approvisionnement grâce à de meilleures pratiques, une planification plus adéquate et de léquipement moderne. Les objectifs du programme ont généralement été atteints et plusieurs résultats des travaux sur les combustibles forestiers ont été mis en œuvre dans les opérations.

Mots clés : récolte et transport des combustibles forestiers, programme coopératif, bioénergie, utilisation des connaissances

${ }^{1}$ Skogforsk, Uppsala Science Park, SE-751 83 Uppsala, Sweden; maria.iwarssonwide@skogforsk.se 


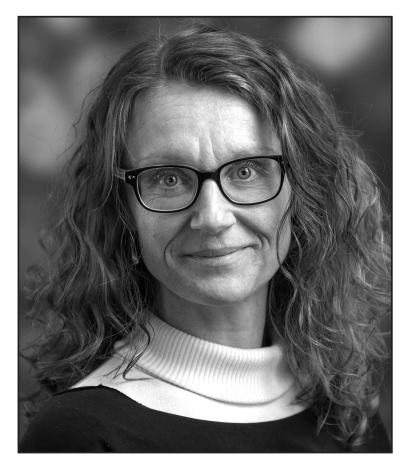

Maria Iwarsson Wide

\section{Background}

Forest fuel is playing an increasingly important role in our energy supply. A worldwide focus on the issue of climate change has resulted in both national and global forces calling for and promoting the transition to energy production based on renewable sources and bioenergy. In Sweden, one of the world's major forestry countries, bioenergy is almost synonymous with forest fuel.

Today, bioenergy accounts for approximately $130 \mathrm{TWh}^{2}$ or $35 \%$ of Swedish energy consumption, of which forest fuel, i.e., logging residues from felling and small trees from thinning activities, contributes $10-15 \mathrm{TWh}$. The goal to increase the proportion of biofuel in energy production is largely based on the potential to considerably increase the harvest of forest fuel. This potential is equivalent to an annual harvest of 40-60 TWh.

Today's production systems are the result of around 35 years of development and routine rationalisations. If forest fuel volumes are to be increased, the efficiency of production systems must be greatly improved. This can be done by integrating the forest fuel flows with other wood flows from the forest and in the systems of users/fuel processors and energy producers. This requires both technical innovation and development of control systems and decision support tools to improve utilisation of resources and yield value. Consequently, major and applied R\&D initiatives are required in close collaboration with the relevant sectors. More intensive forest fuel harvest also increases the risks of impaired growth and undesirable environmental effects in our forests.

\section{Efficient Forest Fuel Supply Systems [ESS]}

The R\&D program Efficient Forest Fuel Supply Systems (ESS) was run between 2007 and 2015 in the form of a broad collaboration between the Swedish Energy Agency and relevant sectors with the aim of developing forest fuel activities. The program was open for applications, and ESS thereby took the form of a network. Part of the ESS program involved training initiatives, and national expertise was built up and organised during the course of the program.

\section{Vision}

The vision was that forest fuel flows would be integrated with other raw material flows in relevant sectors, thereby ensuring an economically, environmentally and socially sustainable supply of forest fuel.

\footnotetext{
${ }^{2}$ Energy production or consumption is often expressed as terawatt hours (TWh) for a given period that is often a calendar or financial year. One TWh is equivalent to a sustained power of approximately 114 megawatts for a period of one year.
}

\section{Objectives and aims}

The objective was to help create the necessary technical and financial conditions to meet the increasing demand for forestbased fuel. By developing more efficient production systems for forest fuel, more of the potential can be realised in a longterm and sustainable way and in larger geographical areas than is the case today. This will enable forest fuel to make a greater contribution to fuel supply in different parts of the energy sector, and make it easier to ensure products meet the specific needs of different users. More efficient production systems will also assure long-term domestic wood supply to both the energy sector and forest industry. Reduced costs are seen as the main way of improving profitability. In the future, forest biomass can also be given a higher processing value, such as in the production of vehicle fuels, materials and chemicals.

\section{Criteria for success}

The results of the program were to:

- Increase knowledge, awareness and engagement regarding forest fuel issues among stakeholders and players, thereby generating greater consensus on wood supply in the sectors concerned;

- Promote the development of new technology, new applications, and new knowledge, thereby ensuring that more and cheaper forest fuel reaches the market;

- Increase the number of jobs and new enterprises, not least in rural areas;

- Broaden the academic expertise base in the forest fuel area; and,

- Produce and implement a good knowledge base to meet the needs of decision-makers and other players.

\section{Funding and organisation}

The program was funded by companies and organisations in the sectors concerned (forestry, transport and energy) by Skogforsk (Forest Research Institute of Sweden), and by the Swedish Energy Agency. Total funding was SEK 130 million, the equivalent of approximately SEK 17 million/year. The activities in the program were steered by a board comprising strategic leaders in the funding bodies and scientific experts. The board made formal decisions on which projects would receive support through the program.

A fuel technology collaboration group, comprising operative management personnel in participating companies, helped to identify development and research needs, and helped in the process from project concept to completed application. This group also served as a forum for discussion and sharing of experiences in development issues.

\section{Project implementation}

The program spanned both short- and long-term goals, and was strongly application- and problem-oriented. A broad approach was adopted. The program was led and administered by Skogforsk and was implemented in close collaboration with forest owners, forest fuel producers and users, and manufacturers of machines, equipment and systems. Skogforsk has a firm footing in the sectors concerned, thereby ensuring a strong financial base for the programme. Skogforsk also has a long tradition and experience of $R \& D$ in forest fuel. 
The work was carried out in the form of clearly defined projects, studies and activities by both internal and external working groups and a mixture of these. In order to provide the program with the right mix of expertise, other research organisations were permitted to apply for project funding. Calls for applications for funding were made three to four times a year.

\section{Communication plan and dissemination of results}

The primary target groups were administrative and line staff working in forestry, fuel production and bioenergy use. The program activities were also aimed at suppliers of machines, equipment and systems, and instructors at various levels.

All results were presented in such a way that these target groups could access them in order to implement them as quickly as possible to provide practical benefit and added value. Results were presented through courses and conferences, films, online, and via less formal meetings, such as field studies, excursions, and seminars.

Skogforsk has a strong tradition of disseminating results and transferring knowledge. The projects in the program have been described and summarised in two syntheses, showing what was achieved in the R\&D work. The reports also described how the results could improve the efficiency of forest fuel systems, as well as the current and expected role of forest fuel in the energy system.

Broad support was attained by involving stakeholders operatively in project planning and as project pilots in implementation. A clear indication of the strength in the program was the extensive implementation work that took place amongst the players. This meant a rapid turnover of results, and enabled implementation of efficiency improvements in practical operation. The great need and broad impact was shown by the scale of involvement and positive response during activities in which knowledge acquired during the program was disseminated.

The program involved approximately 150 projects. The overall conclusion is that there is great potential for considerably reducing system costs relating to forest fuel harvest. Efficiency can be improved throughout the production chain, through a combination of technical system development and planning support of various types.

The program has also helped to assure the long-term supply of skills and expertise by co-funding a number of doctoral student positions. This is of strategic importance because, for many years, the field has attracted limited attention in academia.

Skogforsk is involved in both Nordic and international networks. Within these networks, R\&D activities have been coordinated to avoid duplication of work, to create a broad base of expertise, and to learn from one another. For example, the work has been synchronised with a major EU project, INFRES, in which Skogforsk participated. The program has also involved close collaboration and exchanges with Metla/LUKE (Finland), Norwegian Institute of Bioeconomy Research (Norway), IVALSA (Italy) and FPI (Canada). The collaboration has taken the form of joint projects and continual exchange of information and results.

\section{Reflections and Results}

The first phase of the ESS program, 2007-2011, was a dynamic period for forest fuel, and production grew strongly. New biofuel-based thermal plants were built and existing plants expanded, which increased demand for biofuel, $85 \%$ of which comes from the forest. Utilisation of primary forest fuel (logging residue, small trees, and stumps) increased during the first program period by approximately $50 \%$, but through robust technology and method improvements, costs could be kept at an unchanged level. The forestry sector and its contractors gradually strengthened the supply system through improved skills, better organisation, and advanced equipment. The expansion of forest fuel production was a major reason why Sweden, already by the end of the first program period, reached the EU goal for renewable energy by 2020, the only country to do so.

However, during the second program period, 2011-2015, the positive development levelled off. Demand did not increase as expected for several reasons. Mild winters reduced the need for fuel, and a general economic downturn reduced the overall need for energy. However, even more significant was that the continued expansion of thermal plants started to involve other fuel types, particularly household waste, which is increasingly imported from other EU countries. In Sweden, many environment-related taxes and charges are levied on fossil fuels, which make biofuels competitive. During this period, the price of fossil fuels, including oil, fell dramatically, but there was no corresponding increase in the environmental charges and taxes, so biofuels have become less competitive. This also reduced the demand for wood chips.

The objective of the program was to improve the efficiency of forest fuel harvest with reduced costs, improved quality, and retained profitability for all players involved. Reduced costs and greater added value are seen as the main ways of improving profitability.

The program focused on developing existing and new technology for harvesting forest fuel. For example:

- The work on logging residue primarily involved improving quality, efficiency in forwarding, and decision support to prevent ground damage during harvesting.

- The work on stump harvest involved optimising the handling chain, and reducing ground impact and the amount of contaminants in the material.

- The work on small trees examined extraction in new types of stand, efficient thinning methods, and the potential of multi-tree handling under various conditions.

- A broad survey of comminution (particle size reduction) methods was carried out, with the aim of identifying the best technology in relation to different types of material and the quality required.

- The work on transport technology and logistics focused on developing and demonstrating longer and heavier vehicles, rail-road transports and efficient terminals, but also on how to manage and optimise transports.

- Measurement issues were a natural focal point in the second half of the program. A prioritised project area was to develop and evaluate the technologies and methods that are currently available or that could be developed. 
- Pioneering work was initiated to define relevant assortments of forest fuel from a customer perspective.

A guiding principle in all projects and issues was to investigate what could be done to maximise quality in all stages of the handling chain.

\section{Future challenges}

There is great potential to increase harvest of primary forest fuel; today only one-third of the potential volume is utilised. However, the major fluctuations in demand make it difficult to encourage contractors and players to prioritise forest fuel activities; long-term and reasonably consistent demand is necessary. New market areas will be needed in the future.
Sceptics argue that using forest biomass should not be classified as sustainable use of forest resources, and that the climate benefit is doubtful. This will require communication and networking to influence on decision-makers.

Apart from reducing the total costs, the biggest challenge today is to improve quality aspects that will enable greater harvest and use of primary forest fuel. Here, we still see great potential. We must refine existing technologies and develop new ones for felling, handling and transport, and we must improve consistency, predictability and measurability of the fuel qualities required. 